The content list of the educational module "The Earth: Time Travel" which is treated as a component of the educational course "Across Epochs and Continents" has been outlined. Eight topical units, namely "The Ice Age", "The Silk Route", "Darwin and the Theory of Evolution", "The First Journey Around the World", "The Pyramids of Egypt", "The Seven Wonders of the Ancient World", "World of Plants", and "The Vikings", have been singled out. These topical units have been considered to clarify the issues concerning the background of the planet and spotlight great geographical and scientific discoveries.

The positive effect of the "case"-method presented in the form of contextual drills has been argued. The "case"method has been considered as a strategy to shape an intelligent and community-minded personality. The "case"-method has also been suggested as a complimentary one when educating children who are the representatives of generations $Z$ and Alpha.

The exercises and contextual drills concerning some topical units under consideration have been exemplified. The value of video method along with the reading fragments has been validated. The whole set of drills correlating with the topical unit "The Vikings" has been analysed.

Key words: a video segment, an experimental course, integration, information and communication technologies, educational space.

DOI: https://doi.org/10.32782/2410-0927-2020-12-24

УДК: [811.111+811+112.2+811.161.2]'373.46(045)

Оксана Петренко

\title{
СИНОНІМІЧНІ ВІДНОШЕННЯ НІМЕЦЬКОМОВНИХ ТЕРМІНІВ У ГАЛУЗІ РОБОТОТЕХНІКИ
}

У статті досліджено явище синонімії термінів німецької мови галузі робототехніки на матеріалі 1670 мовних одиниць, відібраних шляхом суцільної вибірки з 16 фахових джерел (фахові тексти з робототехніки). Окреслено причини, які зумовлюють потребу в дослідженні синонімічних відношень німецькомовних термінів робототехніки, предмета, об'єкта, методів та завдань. Розглянуто два протилежні погляди на проблему термінологічної синонімії. Ідентифіковано поняття синонім, дублет, синонімія, синонімічні відношення. Проведено зіставний аналіз синонімічних рядів на семантичному та структурному рівнях. Якщо більшість визначень синонімії в загальнолітературній мові грунтуються на близькості значення лексичних одиниць, то термінологічні синоніми визначаються як мовні одиниці, абсолютно тотожні за значенням і взаємозамінні в будь-якому контексті, а поняття «термінологічна синонімія» найбільш адекватно виражає наявність декількох найменувань для одного означуваного. 3 погляду походження та структурно-словотвірних особливостей виокремлено вісім різновидів груп синонімів, до складу яких увійшли 159 синонімічних пар досліджуваної термінології: іншомовний термін - німецький термін (19\%), різнокореневі складені слова (17 \%), спільнокореневі складені слова (14 \%), терміни-однословибагатокомпонентні складені слова (13\%), німецькі різнокореневі синоніми (13\%), повне (німецьке або іншомовне) та скорочене найменування (12\%), терміни-композити - термінологічні сполучення (9 \%), німецькі однокореневі синоніми - (3\%). Найбільший синонімічний пласт у досліджуваній термінології складають дублетні терміносиноніми іншомовного та німецького походження. Це пов'язане із запозиченням іншомовних слів та штучним утворенням термінів на базі німецької мови 3 метою уникнення запозичень та створення власних термінів. Рекомендується у фаховій мові уникати синонімічних термінологічних найменувань та узаконювати лише одне найменування. Визначено перспективи подальших досліджень лексико-семантичної організації німецькомовної терміносистеми в галузі робототехніки.

Ключові слова: термін, терміносистема робототехніки, синонім, синонімія, синонімічні відношення.

Вступ. Останнім часом з інтенсивним розвитком суспільства, науки і нових технологій все більшого значення в лінгвістиці набувають дослідження, присвячені проблемам лексикосемантичних відношень терміносистем різних наук. У зв'язку з цим стає очевидною актуальність дослідження: вироблення єдиної впорядкованої термінології в галузі робототехніки, яка була б спрямована на усунення наявних протиріч, тобто на реалізацію принципу однозначності в розкритті поняття, що стосується певного терміна. На особливу увагу заслуговує питання термінологічної синонімії, пов'язане із проявами парадигматичних зв'язків у термінологічному просторі, постає проблема надмірності засобів формального вираження понять, на позначення якої вживаються такі терміни, як: термінологічна варіантність, термінологічна синонімія, дублетність або еквівалентність термінів. 
Довгий час термінознавці (О. С. Ахманова, А. С. Д’яков, Л. А. Капанадзе, А. П. Коваль, Д. С. Лотте, О. М. Толікіна, та ін.) заперечували явище синонімії. В той час як інші (В. П. Даниленко, В. І. Михайлов, О.О. Реформатський), навпаки, підтримували існування синонімів. Таким чином утворивши два протилежні погляди щодо розв'язання проблеми термінологічної синонімії. В сучасній лінгвістиці змінилось ставлення до досліджень цієї проблеми на користь наявності синонімічних відношень у термінології (С. І. Вовчанська, С. В. Гриньов， В. Л. Іващенко， В. М. Лейчик， Г. П. Мацюк， Т. І. Панько, Л. О. Симоненко, O. В. Суперанська, М. Д. Степанова, Н.-R. Fluck та інші). Класифікації термінів-синонімів на матеріалі різних терміносистем розглядали в своїх працях Ю. Д. Апресян, І. М. Кобозєва, I. М. Кочан, М. О. Кронгауз, О. А. Мартиняк, Т. А. Михайлова, О. А. Старченко.

Метою статті є дослідити німецькомовні терміни робототехніки, пов'язані синонімічними відношеннями. Завдання розвідки полягають у з'ясуванні типів синонімів робототехніки німецької мови, їхнього походження. Джерельну базу дослідження становлять терміни в галузі робототехніки (1670 мовних одиниць), вилучені з фахових текстів (16 фахових джерел).

Методи та методики дослідження. Методологія дослідження грунтується на засадах застосування загальнонаукових (методи діалектики: індукції, дедукції та функціонального підходу) і спеціальних методів та методик аналізу мовного матеріалу лінгвістики. Методом суцільної вибірки проводився процес селекції мовленнєвого матеріалу 3 фахових текстів робототехніки; описовий метод, аналіз словникових дефініцій та семантико-компонентний аналіз використовувались для цілісної інвентаризації та систематизації аналізованого матеріалу; дистрибутивний аналіз - для визначення й опису семантичної структури досліджуваних термінів робототехніки; методика квантитативно-квалітативного аналізу полягала у визначенні частотності досліджуваного мовного явища.

Результати та дискусії. Необхідно зазначити, що в лінгвістиці існують два протилежні погляди на розв'язання проблеми термінологічної синонімії.

Прихильники першої концепції наголошують, що відсутність синонімів $є$ однією 3 нормативних вимог, що висуваються до систематизованого терміна $\mathrm{i}$ до уніфікованої та стандартизованої терміносистеми. Науковці категорично заперечують існування в термінології явища синонімії і визнають лише наявність дублетів серед них. Так, Л. А. Капанадзе вважає: «не існує термінів близьких за значенням, є термінологічні дублети» [5, с. 78], О. М. Толікіна переконана, що «синонімії ...в термінологічних системах немає. Те, що звичайно вважається термінологічною синонімією, являє собою явище дублетності, яке поширене i в загальнонародній мові». Підтримуючи цю думку, Л. О. Чернишова відзначає, що поняття «синоніми» та «синонімія» належать до галузі вивчення загальнолітературної мови, оскільки синонімія передбачає розгляд нюансів відмінностей, а в термінології можна говорити лише про дублетність [15, с. 17]. Між дублетами відсутні ті відношення, які організують синонімічний ряд, вони позбавлені емоційно-експресивних, стилістичних та смислових опозицій, кожен дублет може відрізнятися від іншого лише структурою або етимологією. Відстоюючи позиції термінологічної дублетності. І. С. Квітко стверджує, що терміни, які співвідносяться з одним і тим самим науковим поняттям в одному термінологічному полі, є не синонімами, а дублетами, оскільки мають одну дефініцію $[6$, с. 98]. 3 появою праць вітчизняних лінгвістів В. Д. Даниленко, Т. Р. Кияка, О. В. Крижанівської, Н. П. Кузьміна, Т. І. Панько та інших - у термінознавстві формується менш категоричний i більш реалістичний погляд на явище термінологічної синонімії, згідно з яким існування варіантних засобів вираження одного позначуваного терміна визнається об'єктивно виправданим та функційно зумовленим. Прихильники цього підходу (Л. І. Антошкіна, І. В. Забело, К. О. Захарчук, С. Г. Казаріна, I. М. Кочан, С. М. Кришталь, В. А. Татаринов, Р. С. Цаголова та інші) зазначають, що закони мови універсальні й термінологія як різновид загальнолітературної мови їм також підпорядковується. Отже, синонімія в термінології - це явище цілком закономірне.

На думку прибічників загадкової концепції, у термінології існує чимало причин та передумов для виникнення й співіснування синонімічних найменувань одного поняття. Д. С. Лотте у свій час зауважував, що використання термінів-синонімів $\epsilon$ виправданим, коли 
вони вживаються задля вираження різних ознак того ж самого поняття, тобто сприяють усебічній характеристиці об'єктів [9]. Н. П. Кузьмін із цього приводу стверджує: «Синонімія відбиває пізнавально-узагальнюючу діяльність людського розуму. Будь-якому об’єктові властиві численні ознаки. Декілька різних сторін сприйняття одного й того самого об'єкта зумовлює появу кількох різних найменувань, у яких зафіксовані його різні характерні ознаки. Якщо ж у процесі функціонування якісь синоніми зникають, то це не тому, що вони були синонімами, а тому, що не відповідали вимогам норми» [8, с. 78].

Виправданим можна вважати й використання синонімічних термінопозначень у письмовому та усному мовленні фахівців внаслідок бажання уникнути одноманітного повторення тих самих слів і замінити їх семантично адекватними термінологічними одиницями. Так, на думку М. С. Зарицького, як незаперечний постулат можна оцінювати твердження про те, що «синонімія прийнятна на перехідному, «сировинному» етапі, до усталення, уніфікації терміносистеми ... проте їі шкідливість виявляється на кінцевому етапі». Синонімія необхідна на етапі пошуку, випробування і відбору термінів, адже «як чинник термінотворчого процесу містить у собі суперечливість, яка $є$ рушійною силою будь-якого об'єкта» [5, с. 22]. В. Д. Даниленко під синонімом у термінології розуміє «синонімічний варіант терміна» або просто «варіант терміна» як варіантне найменування одного й того самого поняття в конкретній терміносистемі [4, с. 152]. К. Я. Авербух, навпаки, вважає доцільним проводити чітку диференціацію понять «синонім» та «варіант», наголошуючи на тому, що «явище синонімії пов'язано із різними називаннями одного предмета, співвіднесеного із різними поняттями, а варіювання засновано на відмінному називанні одного поняття», дублети при цьому розглядаються дослідником як один із різновидів варіантів [1Ошибка! Источник ссылки не найден., с. 41]. С. В. Гриньов вважає всі вищезазначені явища рівнозначними, констатуючи, що рівнозначні терміни - це терміни з однаковим або подібним значенням, які вживаються для називання одного поняття [3, с. 12]. Проте найбільшого поширення серед термінознавців набуває саме термін «синонім», ним оперують такі науковці, як Б. Н. Головін, С. Г. Казаріна, Т. Р. Кияк, 3. І. Комарова, Н. 3. Котелова, I. М. Кочан, О. В. Крижанівська, Н. П. Кузьмін, Т. І. Панько, В. А. Татаринов та інші.

Відомо, що синоніми пояснюють один і той самий предмет одного предметнопонятійного поля 3 різних точок зору. Однак, висловлюючи одне поняття, синоніми розрізняються відтінками значення або стилістичним забарвленням, що здебільшого не перешкоджає їх взаємозамінності в контексті. Якщо більшість визначень синонімії в загальнолітературній мові «грунтується на близькості значення лексичних одиниць, то термінологічні синоніми визначаються як мовні одиниці, абсолютно тотожні за значенням i взаємозамінні в будь-якому контексті», а поняття «термінологічна синонімія» найбільш адекватно виражає наявність декількох найменувань для одного означуваного». 3 таким твердженням співвідноситься також думка М. А. Ванштейна про те, що в термінології поява

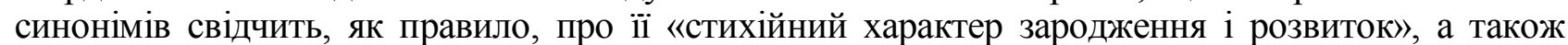
властивість термінології до «надмірності засобів формального вираження понять» [2, с. 16].

Однак численні факти синонімічних відношень у німецькій термінології робототехніки не дозволяють прийняти тезу про надмірність засобів формального вираження понять, оскільки, nо-перше, мова і їі підсистеми, в тому числі і термінологічна система, прагнуть до економії. Дублетні засоби цьому не сприяють.

По-друге, розвиток суспільства і науково-технічного прогресу супроводжується постійним збагаченням вже наявного термінологічного апарату, необхідного для позначення новоутворених предметів, явищ і процесів та їх уточнення й деталізації. А одним із засобів фіксації в мові процесів уточнення і деталізації одного і того самого явища є синонімічні одиниці. Очевидно, що поряд 3 цими процесами виникає проблема смислової адекватності мови, тобто вміння вибирати в словниковому складі певної мови саме ті засоби, які точно передають думку.

По-третє, німецька термінологія робототехніки, як і терміносистеми інших наук, $є$ за своїм складом міжмовною, оскільки до формування та розвитку цієї термінології долучилися англійські, латинські і французькі запозичення. Основними причинами цього явища стало 
«панування латини як міжнародної мови науки», розвиток робототехніки в напрямку глобалізації, а також співпраці дослідників різних країн, у результаті чого відбувався обмін термінологією. Паралельно 3 іншомовними термінами в силу різних причин у німецькій мові 3'являлися власні мовні одиниці. Об'єктивним наслідком такого процесу є утворення термінологічних синонімів, а саме міжмовних синонімів, що мають поряд із загальним семантичним компонентом відмінність, зумовлену такою опозицією, як «свій - чужий». Отже, вже через ці відмінності доволі суперечливим $є$ погляд, що термінам робототехніки властива абсолютна синонімія.

3 моменту визнання синонімії в термінології зроблені численні спроби класифікації термінів-синонімів на матеріалі тієї чи тієї конкретної терміносистеми. Т. В. Михайлова пропонує розрізняти в термінології абсолютні, відносні й комплексні синоніми [11Ошибка! Источник ссылки не найден., с. 11]. I. М. Кочан класифікує синоніми в науково-технічній термінології, беручи за основний критерій поділу особливості структури слів. Зокрема, вона виокремлює одноструктурні терміни-синоніми (терміни-варіанти, або словотвірні синоніми; різнокореневі відповідники термінів; терміни, різні за походженням) і різноструктурні синоніми (терміни, утворені аналітичним і морфологічним способами; однокореневі терміни-синоніми) [7, c. 34]. За ступенем тотожності, близькості значень, здатності до взаємозаміни та нейтралізації в контексті Ю. Д. Апресян та М. А. Кронгауз поділяють синоніми на абсолютні (повні) та відносні (часткові). О.А. Мартиняк виділяє лексичні, словотвірні й синтаксичні терміни-синоніми. Формальні видозміни того самого слова, коли поряд вживають дві форми одного слова, які можуть мати відмінності на фонетичному та морфемному рівнях або у формах роду та числа, дослідниця вважає варіантами [10, с. 102].

Ураховуючи результати аналізу німецької термінології робототехніки 3 погляду походження та структурно-словотвірних особливостей, виокремлюємо вісім типів синонімічних груп синонімів, до складу яких увійшли 159 синонімічних пар термінів, причому деякі 3 них одночасно належать до двох синонімічних груп (див. табл. 1).

1. Іншомовний термін - німецький термін складає 19\% синонімів: Robot Language - die Robotersprache; der Computer - der Rechner, die Maschine, data bank - die Datenbank, hydraulics - die Hydraulik тощо. Ці терміни-синоніми по-різному функціонують у сучасній німецькій мові: деякі запозичені терміни вживаються частіше, ніж їх німецькі еквіваленти, наприклад: der Service, Programming, Robot вживаються частіше, ніж die Bedienung, die Programmierung, der Roboter. Під час дослідження німецької мови робототехніки було встановлено, що на сучасному етапі переважають англомовні запозичення (85 \%), що зумовлено насамперед світовим статусом англійської мови.

Синонімічні відношення в німецькій термінології робототехніки

Таблиця 1

\begin{tabular}{|c|l|c|c|l|}
\hline № & \multicolumn{1}{|c|}{ Групи синонімів } & $\begin{array}{c}\text { кількість } \\
\text { синонімів }\end{array}$ & $\begin{array}{c}\text { \% всіх } \\
\text { синонімів }\end{array}$ & \multicolumn{1}{|c|}{ Приклади } \\
\hline $\mathbf{1}$ & $\begin{array}{l}\text { Іншомовний термін } \\
\text { німецький термін }\end{array}$ & 30 & $19 \%$ & $\begin{array}{l}\text { Robot Language - die } \\
\text { Robotersprache }\end{array}$ \\
\hline $\mathbf{2}$ & Різнокореневі складені слова & 27 & $17 \%$ & $\begin{array}{l}\text { der Serviceroboter - } \\
\text { derBedienungsroboter }\end{array}$ \\
\hline $\mathbf{3}$ & $\begin{array}{l}\text { Спільнокореневі складені слова } \\
\text { die Laufmaschine - der } \\
\text { Laufroboter }\end{array}$ \\
\hline $\mathbf{4}$ & $\begin{array}{l}\text { Однокомпонентні терміни - } \\
\text { багатокомпонентні складені } \\
\text { слова }\end{array}$ & 22 & $14 \%$ & $\begin{array}{l}\text { der Arm } \\
\text { Roboterarm }\end{array}$ \\
\hline $\mathbf{5}$ & $\begin{array}{l}\text { Німецькі різнокореневі } \\
\text { синоніми }\end{array}$ & 20 & $13 \%$ & der Geber-der Sensor \\
\hline
\end{tabular}




\begin{tabular}{|c|c|c|c|c|}
\hline 6 & $\begin{array}{l}\text { Повне } \\
\text { iншомовне) } \\
\text { найменуванья та }\end{array}$ & 19 & $12 \%$ & $\begin{array}{l}\text { simulation of machining } \\
\text { and robot tasks - SMART }\end{array}$ \\
\hline 7 & Терміни- композити - ТС & 15 & $9 \%$ & $\begin{array}{l}\text { der Mobilroboter } \\
\text { ortbeweglicher Roboter }\end{array}$ \\
\hline 8 & однокореневі & 5 & $3 \%$ & $\begin{array}{l}\text { die Robotertechnik - die } \\
\text { Robotik }\end{array}$ \\
\hline \multicolumn{2}{|c|}{ Усього } & 159 & $100 \%$ & \\
\hline
\end{tabular}

2. Різнокореневі складені слова становлять $17 \%$ синонімів (див. табл. 1): die Maschinensprache - die Robotersprache, der Serviceroboter - der Bedienungsroboter; die Maschinentechnik - die Robotertechnik; der Automobilbau - die Automobilindustrie; der Verpackungsroboter - der Packroboter; der Manipulator - das Handhabungsgerät, der Roboterarm.

3. Спільнокореневі складені слова складають $14 \%$ синонімів (див. табл. 1): das Hebezeug - der Hebezug; die Laufmaschine - der Laufroboter; das Baumuster - die Bauform; der Fertigungsprozess - das Fertigungsverfahren; das Handhabungsgerät-der Handhabungsroboter.

Інше джерело синонімії в сучасній німецькій термінології робототехніки пов'язане 3 тенденцією до семантичної конденсації термінів, тобто намаганням відтворити складне поняття мінімальною кількістю лексичних одиниць:

4. Однокомпонентні терміни - багатокомпонентні складені слова становлять 13,2 \% синонімів (див. табл. 1): der Akku - der Akkumulator; der Kommutator - die Kommutatormaschine; der Arm - der Roboterarm.

5. Німецькі різнокореневі синоніми складають 13 \% синонімів (див. табл. 1): die Einheit der Block, die Zelle, das Arbeitsorgan, das Gerät, das Glied, das Element; der Geber-der Sensor; der Bau - die Form, der Modus, der Baukasten; die Eingabe - die Einführung; das Muster-das Modell, das Baumuster, die Bauform, das Maket; der Verdichter - der Kompressor; der Soft Sensor - der Virtual Sensor; die Grundlage - die Basis.

6. Повне (німецьке або іншомовне) та скорочене найменування становлять 12 \% синонімів (див. табл. 1): Basic Input-Output system - BIOS; Computer-Aided Software Engineering CASE; Computerized Numerical Control-CNC; Random Access Memory-RAM; Global Positioning System - GPS; Remote Method Invocation - RMI; remote manipulator system - RMS; Robot Programming Language - RPL; simulation of machining and robot tasks - SMART; Welt-koordinaten (world coordinates) - WC; computer-aided design - die CAD-Werkzeuge; computer numerical control - die CNC-Steuerung; forward thinking system - das FTS-System; global positioning system der GPS-Sensor; Personenkraftwagen - Pkw-Technik; Punkt zu Punkt Steuerung - Synchron-PTP. Переважають скорочення іншомовного походження, здебільшого з англійської мови. В усному мовленні переважають повні та скорочені форми, а в письмовому частіше вживаються скорочені.

7. Терміни-композити - терміни-словосполучення складають $9 \%$ синонімів (див. табл. 1): die Kreisbewegung - die Drehbewegung Rotation; die Translation - die Geradlinige Bewegung; der Mobilroboter - ortbeweglicher Roboter.

8. Німецькі однокореневі синоніми складають 3 \% синонімів (див. табл. 1): die Robotertechnik - die Robotik; industrial-industriell; der Körper-der Korpus.

Грунтуючись на класифікації В. А. Татаринова [13] та спираючись на праці Ю. Д. Апресяна, І. М. Кобозевої, М. А. Кронгауза, О. А. Старченко та інших, у досліджуваній термінології робототехніки виокремлюємо два різновиди термінологічних синонімів: абсолютні (точні, повні) синоніми та часткові (відносні, неточні, неповні, квазі-синоніми), які підлягають подальшій диференціації:

1. Абсолютні терміни, що мають однакове значення (абсолютні синоніми, або дублети), наприклад: der Geber - der Sensor; der Bau - die Form, der Roboter - die Robotik, die Maschinensprache - die Robotersprache. Можливість паралельного функціонування дублетів у 
тексті загальновідома i давно усталена практикою, хоча варто уникати синонімічних термінологічних найменувань у фаховій мові.

2. Часткові терміни (часткова синонімія) - синоніми за сигніфікатом, тобто лексичні одиниці, які мають при однаковому сигніфікативному значенні різні знаки та позначають різні реалії, об’єкти. У досліджуваній термінології з робототехніки було виявлено значну кількість таких термінів-синонімів, наприклад: die Einheit-der Block, die Zelle, das Arbeitsorgan, das Gerät, das Glied, das Element; der Soft Sensor - der Virtual Sensor.

Висновки. Отже, найбільший синонімічний пласт у термінології з галузі робототехніки складають дублетні терміносиноніми іншомовного та німецького походження (19\%). Поява таких синонімічних рядів пов'язана із запозиченням іншомовних слів, особливо 3 англійської мови та штучним утворенням термінів на базі німецької мови з метою уникнення запозичень та створення власних термінів. Що стосується термінологічних стандартів, то рекомендується у фаховій мові уникати синонімічних термінологічних найменувань та узаконювати лише одне найменування. Проте зовсім уникнути синонімів неможливо, адже постійний розвиток науки й техніки зумовлює появу нових понять та сприяє добору найбільш вдалих і точних назв, що неодмінно супроводжується виникненням синонімічних пар.

Подальші дослідження в цьому напрямку сприятимуть остаточному формуванню німецькомовної термінології робототехніки, допоможуть з'ясувати механізми утворення терміносистеми робототехніки, створити нові словники, глосарії в галузі робототехніки та суміжних галузей науки, що $\epsilon$ вкрай неохідним на сучасному етапі розвитку науково-технічної термінології.

\section{References}

1. Averbuh, Kostantin. 1986. "Terminologicheskaya variantnost: teoreticheskiy i prikladnoy aspekty". Voprosy jazykoznania 6: 38-49.

2. Vainshtein, Mark. A. 2000. "Sopostavitelnyi analiz leksikograficheskoi terminologii v angliyskom i russkom yazykah". PhD diss., Moskwa.

3. Grinev, Sergei. 1993. Vvedenie v terminovedenie. Moskwa: Moskovskiy litsei.

4. Danilenko,Valeriy. 1977. Russkaya terminologiya. Opyt lingvisticheskogo. Moskwa: Nauka.

5. Kapanadze, Lamara. 1965. "O poniatiyakh «termin» i «terminologiya»". Razvitie leksiki sovremennogo russkogo jazyka. Moskva: Nauka75-85.

6. Kvitko, Iryna. 1976. Termin v nauchnom dokumente. Lvov: Vysshaya shkola.

7. Kochan, Iryna. 1992. "Synonimiya u terminolohiyi". Movoznavstvo 3: 32-34.

8. Kuzmin, Nikolai. 1970. "Normativnaya i nenormativnaya specialnaya leksika". Lingvisticheskie problemy nauchno-tehnicheskoj terminologii. Moskva : Nauka 68-81.

9. Lotte, Dmitriy. 1961. Osnovy postroeniya nauchno-tehnicheskoi terminologii. Moskva: Akad. nauk SSSR.

10. Martynyak, O. 2008. "Yavyshhe synonimiyi u terminologichnii leksytsi". Visnyk Nacionalnoho universytetu «Lvivska politekhnika» 620: 100-103.

11. Mykhailova, Tetiana. 2003. "Antonimichni vidnoshennya ukrayinskykh naukovotekhnichnykh terminiv yak movne yavyshhe ta subiekt leksykohrafiyi". Ukrayinska terminolohiya $i$ suchasnist 5: 295-296.

12. Petrenko, Oksana. 2019. "Strukturno-semantychni osoblyvosti nimetskomovnoyi terminolohiyi v haluzi robototekhniky". $\mathrm{PhD}$ diss., Zaporizhzhia.

13. Tatarinov, Viktor. 2006. Obshheye terminovedenie: entsyklopedicheskii slovar. Moskwa: Moskovskiy litsei.

14. Tolikina, Elena. 1970. "Nekotorye lingvisticheskie problemy izucheniya termina". Lingvisticheskie problemy nauchno-tehnicheskoi terminologii. Moskwa : Nauka 53-67.

15. Chernyshova, Larisa. 1990. "Polileksemnye terminy v yazyke i rechi”. PhD diss., Moskwa.

Петренко Оксана. Синонимические отношения немецкоязычных терминов в области робототехники. В статье исследуется явление синонимии терминов немецкого языка области робототехники на материале 1670 языковых единиц, отобранных путем сплошной выборки из 16 профессиональных источников (профессиональные тексты по робототехнике). Определены причины, обусловливающие необходимость в исследовании синонимических отношений немецкоязычных терминов робототехники, предмета, объекта, методов и задач. Рассмотрены два противоположных взгляда на решение проблемы терминологической синонимии. Идентифицировано понятие синоним, дублет, синонимия, синонимические отношения. Проведено сопоставительный анализ синонимических рядов на семантическом и структурном уровнях. Если большинство определений синонимии в общелитературном языке основываются на близости значения лексических единиц, то терминологические синонимы определяются как языковые единицы, абсолютно тождественны по значению и взаимозаменяемые в любом контексте, а понятие «терминологическая синонимия» наиболее адекватно выражает наличие нескольких наименований для одного обозначаемого. С точки зрения происхождения и структурно- 
словообразовательных особенностей, выделены восемь разновидностей синонимических групп синонимов, в состав которых вошли 159 синонимических пар исследуемой терминологии: иноязычный термин - немецкий термин (19\%), разнокоренные составные слова (17\%), однокоренные составные слова (14\%), термины-однословы многокомпонентные составные слова (13\%), немецкие разнокоренные синонимы (13\%), полное (немецкое или иноязычное) и сокращенное наименование (12\%), термины-композиты - терминологические сочетания (9\%), немецкие однокоренные синонимы - (3\%). Наибольший синонимический пласт в исследуемой терминологии составляют дублетные терминосинонимы иноязычного и немецкого происхождения. Это связано с заимствованием иностранных слов и искусственным образованием терминов на базе немецкого языка во избежание заимствований и создание собственных терминов. Рекомендуется в профессиональной речи избегать синонимических терминологических наименований и узаконивать только одно наименование. Определены перспективы дальнейших исследований лексико-семантической организации немецкоязычной терминосистемы в области робототехники.

Ключевые слова: термин, терминосистема робототехники, синоним, синонимия, синонимичные отношения.

Petrenko Oksana. Synonymous Relations of German-Speaking Terms in the Field of Robotics. The article investigates the phenomenon of synonymy of terms of the German language in the field of robotics on the material of 1670 language units, selected through a continuous sample of 16 professional sources (professional texts in robotics). The reasons that determine the need to study the synonymous relations of German-language terms of robotics, as well as subject, object, methods and tasks are outlined in this research. Two opposing views on the solution of the problem of terminological synonymy are considered in the article. The concept of synonym, doublet, synonymy, synonymous relations was identified. The comparative analysis of synonymous groups on semantic and structural levels is conducted. Most definitions of synonymy in general literary language are based on the proximity of the meaning of lexical units, terminological synonyms are defined as linguistic units, absolutely identical in meaning and interchangeable in any context, and the concept of "terminological synonymy" most adequately expresses the presence of several names for one meaning. In terms of origin, structural and word-forming features, eight varieties of synonymous groups of synonyms were distinguished, comprising 159 synonymous pairs of the studied terminology: foreign term - German term (19\%), mixed root words $(17 \%)$, common root words $(14 \%)$ ), single-word terms - multicomponent compound words (13\%), German mixed-root synonyms (13\%), full (German or foreign language) and abbreviated name (12\%), term-composites - terminological word combinations ( $9 \%$ ), German root synonyms - (3\%). The largest synonymic layer in the terminology under study is the doublet synonyms of foreign and German origin. This is due to the borrowing of foreign words and the artificial formation of terms based on the German language in order to avoid borrowing and to create their own terms. It is recommended to avoid synonymous terminological names in the professional language and legalize only one name. The prospects for further research of the lexical-semantic organization of the German-speaking term system in the field of robotics have been determined.

Key words: term, robotics terminology, synonym, synonymy, synonymous relations.

DOI: https://doi.org/10.32782/2410-0927-2020-12-25

УДК $821.161 .2(71)^{\prime} 06(092)$

Ольга Плєщкова, Ірина Калиновська, Еліна Коляда

\section{ІСТОРІЯ РІДНОГО КРАЮ КРІЗЬ ПРИЗМУ ЖИТТЕВОГО І ТВОРЧОГО ШЛЯХУ УКРАЇНСЬКО-КАНАДСЬКОЇ ПИСЬМЕННИЦІ ЛЮБОВІ ВАСИЛІВ-БАЗЮК}

У статті проаналізовано життєвий і творчий шлях Любові Йосипівни Василів-Базюк. Ім'я незламної жінки, родом із волинського села, добре відоме поза межами України. Під час Другої світової війни вона змушена була залишити рідну землю, щоб через десятиліття не раз повернутися сюди, довівши, що серце ії належить Батьківщині. Вона є прикладом сильної українки, яка зуміла залишитися вірною своєму народові.

Сьогодні Любов Василів-Базюк - відома письменниця, науковиця, благодійниця, справжня патріотка, яка, проживаючи за океаном, у Торонто, не пориває зв'язків із Волинню. Вона дбає про будівництво українських церков, організовує збір коштів на відбудову Волинської богословської семінарії, засновує іменні стипендії для студентів, пише книги про події, які є близькими для мільйонів українців.

У творчому і науковому доробку Любові Василів-Базюк, почесної професорки Волинського національного університету імені Лесі Українки, десятки наукових статей, віршів, дописів, десять історичних романів, які написані на основі документальних матеріалів, спогадів власних та очевидців. Наукові статті та романи авторки присвячені трагічним подіям в історії України та Волині зокрема. Письменниця також висвітлює важливі сучасні політичні події та соціальні проблеми життя українців як в Україні, так і в еміграції. Вона пише про своє життя, про те, що вплинуло на іiі характер та як формувалися іiі релігійні та політичні погляди. Любов Василів-Базюк постійно надсилає примірники своїх книг до українських університетів, коледжів, бібліотек.

(C) Плєшкова О., Калиновська I., Коляда Е., 2020 